\title{
CAN ROSES SURVIVE ON REGISTERED LAND?
}

\author{
Alan Dowling
}

\section{Senior Lecturer in Law, The Queen's University of Belfast}

The decisions in the two Re Rose cases ${ }^{1}$ will shortly celebrate their fiftieth birthdays. Both are well known. In Re Rose ${ }^{2}$ the question for the Court of Appeal was whether estate duty was payable following transfers by the registered owner of shares in a company. Liability to duty depended on whether the shares could be said to have been transferred before 10 April 1943. If the shares had been transferred before that date, no liability would exist. If they had not, duty would be payable. The problem was that while the instruments of transfer were dated 30 March 1943, the transfers were not recorded in the company's books until 30 June 1943. The court held that no duty was payable, on the basis that by executing the transfers and handing over the share certificates the registered owner had constituted the transferee beneficial owner of the shares. Evershed MR did not see Milroy v Lord ${ }^{3}$ as preventing the view that the donor was, by the necessary effect of his own deed, a trustee of the legal estate for the donee, pending registration. ${ }^{4}$ Jenkins LJ explained:

"the [transferor] had ... done all he could, in appropriate form, to transfer the whole of his interest, but so far as the legal title was concerned, it was not in his power himself to effect the actual transfer of that, inasmuch as it only could be conferred on the transferees in its perfect form by registration of the transfers." 5

The same conclusion had been reached by the learned judge in the earlier Re Rose case. ${ }^{6}$ The question there for Jenkins J, as he then was, was whether a testator had made an inter vivos gift of his shares in a company. The testator had executed the necessary transfer, but the transfer had not been registered at the time of the testator's death. The court held that as the testator had done everything in his power to divest himself of the shares the gift was effective inter vivos so that the shares did not form part of the testator's estate.

The decisions in the Re Rose cases have been the subject of discussion and strong criticism. ${ }^{7}$ It is not the purpose of this note to recross well-trodden ground, but rather to consider how the decisions in the Re Rose cases apply to transfers of registered land. ${ }^{8}$ As in the case of the transfer of

1 Re Rose, Midland Bank Executor and Trustee Co Ltd v Rose [1949] Ch 78; Re Rose, Rose v IRC [1952] Ch 499.

2 [1952] Ch 499.

3 (1862) 4 De G F \& J 264.

4 [1952] Ch 499, 512.

5 Ibid, 515.

6 [1949] Ch 78.

7 See $e g$ the different views expressed by Sheridan, 'Informal gifts of choses in action' (1955) 33 Can Bar Rev 284 and McKay, 'Share transfers and the complete and perfect rule' (1976) 40 Conv (NS) 139.

8 Although in Pilewska v Haduch (1962) 184 EG 11 Wilberforce J noted that there was little authority on the question whether transfers of registered land 
shares in a company, transfer of land, the title to which is registered at the Land Registry, takes the form of execution of a transfer by the registered owner followed some time later by the registration of that transfer in the Registry. The system of registration of title having been modelled upon the existing registration systems by which stock or shipping could be transferred, it would not be surprising to find the principles upon which the decisions in the Rose cases are based being applied to the transfer of registered land. The implications of the decisions and their application in this context are however uncertain.

\section{ENGLISH AUTHORITIES}

The first occasion ${ }^{9}$ in which a problem similar to that in the Rose cases came before the courts here in relation to registered land appears to be Pilewska v Haduch ${ }^{10}$ in which the plaintiff sought a declaration that she was entitled to a share in a house by reason of a transfer of the property by the registered proprietor. The defendant argued that the transfer was an incomplete gift, and ineffective. Wilberforce $\mathrm{J}$ held first, that the transfer could not be regarded as a voluntary transfer, ${ }^{11}$ but secondly, that on consideration of the relevant provisions of the Land Registration Act 1925 it was not correct to say the document was incomplete. While noting that under the Act a registered estate does not pass until registration, ${ }^{12}$ Wilberforce $J$ went on to point out that the Act allows for the creation of minor interests. ${ }^{13}$ His Lordship held that the deed was effective to transfer an equitable interest in half the proceeds of sale of the property, and granted a declaration to that effect.

Harden $\mathrm{v}$ Thompson ${ }^{14}$ is another first instance decision concerning a voluntary transfer which was not registered. Shortly after the transfer was executed the registered proprietor (the plaintiff) and the transferee had a row which resulted in the plaintiff instructing his solicitors that he had changed his mind about the transfer. The transferee argued on the basis of Re Rose ${ }^{15}$ that the plaintiff had done all that was required of him to perfect the gift, and that the transferee was accordingly entitled to be registered as proprietor. Plowman J decided the case however in favour of the plaintiff on the basis that the plaintiff's purpose in making the gift had failed, and

should be treated in the same way as transfers of shares, there is nothing in the later cases to suggest that the principles in the Rose cases do not apply to registered land.

9 See however Smith v Express Dairy Co Ltd [1954] JPL 45 and Lever Finance Ltd $\vee$ Needleman's Trustee [1956] Ch 375 which raise different questions as to the position of the transferee.

${ }^{10}(1962) 184$ EG 11.

${ }^{11}$ As the transfer contained a covenant by the plaintiff to pay half the instalments of the mortgage on the property. In Re Rose [1952] Ch 499 Evershed MR noted that the transfer to Mrs Rose contained what was in effect a covenant by her, to accept the shares on the conditions imposed on shareholders in the company, thereby relieving the transferor of his liability as corporator. Nonetheless his Lordship found it unnecessary to pursue the question of consideration ([1952] Ch 499, 513).

${ }^{12}$ Land Registration Act 1925, s19; cf. Land Registration Act (NI) 1970, s34(3).

${ }^{13}$ See Land Registration Act 1925, s101.

14 (1969) 212 EG 1364.

15 [1952] Ch 499. 
that the beneficial interest in the property was accordingly held by the plaintiff. ${ }^{16}$

The Rose decisions were however the basis for the decision of the Court of Appeal in Mascall $\mathrm{v}$ Mascall. ${ }^{17}$ This again came to court as the result of a quarrel between the parties to a transfer, following which the registered proprietor (the plaintiff) had changed his mind about the transaction. In an action for a declaration that the transfer was of no effect, the Court of Appeal applied the Rose decisions with the result that the plaintiff's action failed. According to Lawton LJ, the plaintiff:

"had done everything in his power to transfer the house to the defendant. He had intended to do it. He had handed over the land certificate. He had executed the transfer and all that remained was for the defendant, in the ordinary course of conveyancing, to submit the transfer for stamping and then to ask the Land Registry to register his title." 18

The argument, based on section 18 of the Land Registration Act 1925, that the plaintiff could have done more, by himself presenting the transfer for registration, was rejected, as in the ordinary course of events this would be a matter for the transferee.

The latest of the authorities in which the Rose cases have been called in aid to determine questions arising from the execution but not registration of a transfer of registered land is Brown \& Root Technology Ltd v Sun Alliance \& London Assurance Co Ltd. ${ }^{19}$ Here a registered lease contained a provision entitling the lessee to determine the lease at a specified date. A further provision stated that this right of termination was personal to the lessee and would cease to have effect upon the assignment of the lease by the lessee. The lessee executed a transfer of the registered leasehold estate in favour of its parent company. This transfer was not however presented for registration. Some time later the lessee gave notice terminating the lease pursuant to the provision noted. The question for the court was whether this notice was valid.

At first instance ${ }^{20}$ Judge Paul Baker QC, having reviewed the Rose cases, held that the notice was not valid:

"The way I would put it is this. I accept, in effect, the defendant's submissions, that, where it is necessary to fix a date on which the assignment takes place, that date, in my judgment, is the date on which it is completed. The tenant/assignor gives up the property on that date; he has no control over the stamping of the transfer, or its submission to the Land Registry. He becomes a bare trustee for the assignee as regards the legal title. The landlord, a fortiori, has no such control. There is no ground for suggesting that either the assignor or the landlord can compel the assignee to submit the transfer for registration." 21

${ }^{16}$ The case is noteworthy also for Plowman J's discussion of the admissibility of evidence, foreshadowing Tinsley v Milligan [1993] 3 WLR 126.

17 (1984) 50 P \& CR 119

18 Ibid, 125.

19 (1997) 75 P \& CR 223.

${ }^{20}[1996]$ Ch 51.

${ }^{21} \mathrm{Ibid}, 67$. 


\title{
92 Northern Ireland Legal Quarterly [Vol. 50, No. 1]
}

On appeal, the Court of Appeal held that the notice was valid and accordingly that the lease had been determined. The critical question, according to Mummery LJ, was whether there had been an assignment of the lease, and if so, when that event occurred. Gentle v Faulkner ${ }^{22}$ was taken as authority that as between lessors and lessees 'assignment' meant assignment of the legal estate, which would take place only if and when registration took place.

Leaving aside questions of construction and the application of Gentle v Faulkner, the judgment of Mummery LJ illustrates one of the problems which are inherent in the Rose decisions. His Lordship made it clear that the question for determination in Brown \& Root involved a different relationship, and different considerations, to that in the Rose cases. His Lordship explained:

\begin{abstract}
"This case is not a matter of beneficial ownership between parties to the transfer of the lease: the issue of assignment or no assignment affects the legal position of a third party, the lessors, who have given their licence to assign but are not a party to the transfer. As was observed by Jenkins LJ in Re Rose it is necessary to keep clear and distinct the position between the transferor and the transferee and the position of a third party. Transfer of the beneficial title is not, in this context, relevant to the legal relationship between the lessees and the lessors. The issue is not what rights [the assignor] and [the assignee] have against each other, but what rights [the assignor] and [the landlord] have against each other. That is a question of legal, not equitable, rights." 23
\end{abstract}

The fact that for some purposes a gift may on the principles in the Rose cases be regarded as complete, while for other purposes it is incomplete is just one of the difficulties. Other questions requiring determination are, more fundamentally, should anything short of registration suffice for any purposes, and if so, what acts are necessary if the unregistered transfer is to have effect.

\section{COMMONWEALTH AUTHORITIES}

It is not surprising to discover that Commonwealth jurisdictions where systems of retgistration of title have long been in place have encountered the difficulties under consideration. ${ }^{24}$

\section{Anning $v$ Anning}

Differing opinions on the effect of an unregistered voluntary transfer of registered land go back as far as Anning v Anning ${ }^{25}$ in which Griffith CJ considered that if all that remains to be done to complete the transaction could be done by the donee himself, so that he does not need the

22 [1900] 2 QB 267.

23 (1997) 75 P \& CR 223, 230.

${ }^{24}$ For other relevant authorities, not however involving registered land, see Norman v Federal Commissioner of Taxation (1963) 109 CLR 9; Olsson v Dyson (1969) 120 CLR 365; Taylor v Deputy Federal Commissioner of Taxation (1969) 123 CLR 206. See also Zines, Equitable assignments: when will Equity assist a volunteer?' (1965) 38 ALJ 337; Seddon, "Imperfect gifts of Torrens title land" (1974) 48 ALJ 13.

25 (1907) 4 CLR 1049. 
assistance of the court, the gift will be regarded as complete. ${ }^{26}$ In the same case however Isaacs $\mathbf{J}$ took the opposite view, saying that if for any reason, including want of registration, the transfer of the legal title is incomplete equity will regard the gift as still imperfect and will not enforce it. ${ }^{27}$ "In such a case," his Honour continued, "the fact that the assignor has done all that he could be required to do is not applicable." 28 The same view appears to be the basis upon which the Alberta Supreme Court held in Smith v Smith ${ }^{29}$ that an unregistered voluntary transfer had been validly revoked even though the donor had handed the transfer and the certificate of title to the donee. The third member of the court in Anning v Anning, Higgins J, appears to have taken the view that what is required is that the donor must have done everything which could have been done, either by the transferor or by the transferee, to perfect the gift, emphasising that "[w] hat the courts look at is what the donor might have done."30 This view has not however proven popular. ${ }^{31}$

\section{Brunker v Perpetual Trustee Co (Ltd)}

Although taking different views, each of the members of the court in Anning v Anning was concerned to see how an unregistered transfer would be seen in Equity. The maxims that "equity will not assist a volunteer" and "equity will not perfect an imperfect gift" are well known. The judgments in Anning differ in how these principles should operate. A different proposition was put forward by Dixon J in Brunker v Perpetual Trustee Co $(\mathrm{Ltd}) \mathrm{.}^{32}$ His Honour considered that difficulties of reconciling the maxims with holding a donor bound by a voluntary unregistered transfer could be circumvented if the transferee were seen as having a statutory right to have himself registered as owner. ${ }^{33}$ Such a right would not depend on the doctrines of equity, and would avoid the need to explain how a transferee could hold an equitable estate in the face of other provisions of the legislation ${ }^{34}$ providing that until registration no dealing would be effective to pass any estate or interest to the transferee. The relevant question, according to Dixon $\mathrm{J}$, is whether by his acts the donor has placed the donee in such a position that under the statute the donee has an indefeasible right to have the transfer registered. ${ }^{35}$

$-$

${ }^{26} \mathrm{Ibid}, 1057$.

${ }^{27} \mathrm{Ibid}, 1069$. See also the view of Herdman J in Scoones v Galvin [1934] NZLR 1004,1022 , that bearing in mind the policy of the relevant New Zealand legislation it was 'very difficult to escape the view that a gift such as was proposed in the present case is never complete until registration of a transfer is actually effected.'

${ }^{28} \mathrm{Ibid}$.

29 (1915) 21 DLR 861.

30 (1907) 4 CLR 1049, 1082. For interpretation of the view of Higgins J see Cullity and Ford, 'Gifts of future income from choses in action' (1966) 30 Conv (NS) 286, 293 and McKay, 'Share transfers and the complete and perfect rule' (1976) 40 Conv (NS) 139, 140 and 142.

${ }^{31}$ See Corin v Patton (1990) 169 CLR 540; Seddon, 'Imperfect gifts of Torrens title land' (1974) 48 ALJ 13; McKay, 'Share transfers and the complete and perfect rule' (1976) 40 Conv (NS) 139; the view of Higgins J appears to be the same as that rejected in Mascall v Mascall (1984) 50 P \& CR 119.

32 (1937) 57 CLR 555.

${ }^{33}$ Ibid, 599.

${ }^{34}$ Real Property Act 1900 (NSW), s41.

35 (1937) 57 CLR 555, 602. 


\section{Northern Ireland Legal Quarterly [Vol. 50, No. 1]}

The proposition that the donee under a voluntary transfer has a statutory right to registration, and that this would provide a satisfactory basis upon which the unregistered transfer cases could be determined, was accepted by Brennan $\mathrm{J}$ in Corin v Patton. ${ }^{36}$ Other members of the court in the same case however were critical of the proposition. Mason CJ and McHugh J thought that later cases had not endorsed Dixon J's view, which "no longer represent[ed] a correct statement of the law in this area." ${ }^{37}$ Deane $J$ found it difficult to discern the reasons by which Dixon $J$ rejected the view that the donee had an equitable estate, if the donor had done what was necessary to make the donee's right to registration indefeasible. ${ }^{38}$ The judgment of Dixon $\mathbf{J}$ should be seen, Deane $\mathbf{J}$ explained, not as establishing a new kind of statutory right, but as identifying the test for determining whether the stage has been reached when a gift is complete and effective in equity. ${ }^{39}$

\section{Corin v Patton}

The relevant test, according to Deane $\mathbf{J}$ in Corin $\mathrm{v}$ Patton, ${ }^{40}$ is whether the donor has done all that is necessary to place the vesting of the legal title within the control of the donee and beyond the recall or intervention of the donor. ${ }^{41}$ Once that stage has been reached the equitable interest in the land vests in the donee, and the donor is bound in conscience to hold the property as trustee for the donee pending registration. Mason CJ and McHugh $J$ stated the principle to be that if an intending donor has done everything that is necessary to effect a transfer of legal title, then equity will recognise the gift. ${ }^{42}$ The question is whether what the donor has done is sufficient to enable the legal transfer to be effected without further action on his part. ${ }^{43}$ If he has, an equity arises enabling the donee to procure the vesting of the legal title in himself. ${ }^{44}$ The other members of the court took different approaches. As we have seen, Brennan J accepted the view of Dixon J in Brunker v Perpetual Trustee Co (Ltd) that the donee has a statutory right to registration which conferred no equitable estate on the donee. Accordingly, on the death of the donor without registration having taken place, the donee had nothing which could prevail against a surviving joint tenant. For the final member of the court, Toohey $\mathrm{J}$, the relevant issue was simply that the transfer from the donor had not been registered at the time the donor died..$^{45}$

\section{SATISFYING THE TEST}

If it is accepted that actions falling short of registration of the donee should suffice for a donee to be regarded as owner of the property

$-$

36 (1990) 169 CLR 540, 570. See also Stefanovic v Petrovic 1989 NSW LEXIS 11052.

${ }^{37} \mathrm{Ibid}, 556$.

${ }^{38}$ Ibid, 581.

${ }^{39} \mathrm{Ibid}, 582$.

40 (1990) 169 CLR 540; Rossiter, 'Corin v Patton in the High Court; the status of a volunteer with respect to Torrens title land before registration' (1990) 64 ALJ 727.

${ }^{41}$ Ibid.

${ }^{42}$ Ibid, 559.

${ }^{43}$ Ibid.

${ }^{44}$ Ibid, 560. See also Edwards v Sir Moses Montefiore Jewish Home 1990 NSW LEXIS 10387.

${ }^{45} \mathrm{Ibid}, 593$. 
transferred, the question becomes what actions will be sufficient. Some principles can be stated with reasonable certainty; other matters present problems. Execution by the donor and delivery of an instrument of transfer in the appropriate form are essential. ${ }^{46}$ The fact that some other matter, such as clearing off the name of a deceased joint owner, has to be attended to before the transferee can be registered, does not prevent the gift from being complete. ${ }^{47}$ As we have seen, the better view appears to be that the fact that the donor could procure registration of the transfer does not prevent the gift being seen as complete. ${ }^{48}$ In Cope v Keen ${ }^{49}$ Kitto J held that what is involved is:

"a at least that the memorandum of transfer should be delivered to the [transferee] by or on behalf of the [transferor] with the intention on his part of then and there parting with it and with the property in it ${ }^{50}$ so that the [transferee] should be entitled as against him to cause the instrument to be registered".

A more difficult issue arises in connection with the land certificate relating to the property. The question is whether a gift can be regarded as complete if the donor hands over an executed transfer but retains possession of the land certificate. In Scoones v Galvin ${ }^{51}$ the New Zealand Court of Appeal considered that in such a case the donor has not done all that is necessary for him to do, and so could revoke the gift. Although Taylor $\mathrm{J}$ in Cope $\mathrm{v}$ Keen $^{52}$ expressed uncertainty as to this requirement under the relevant New South Wales legislation, ${ }^{53}$ the view in Scoones v Galvin was accepted by the Australian High Court in Corin v Patton. ${ }^{54}$ Corin v Patton itself illustrates the problems which can occur with the apparently straightforward requirement that the certificate be produced. There the transferor was one of two joint tenants of land which was mortgaged to a bank. The transferor executed a transfer of her interest in the land to a third party who in turn executed a deed of trust declaring that he held the property on trust for the transferor. The intention was to effect severance of the jointure so that the transferor could leave her share in the land by will. Before the transfer was registered the transferor died. The question for the court was whether the jointure had been severed by the transfer. The court was unanimous in its decision that it had not, though the various members of the court arrived at this decision by different routes. The majority of the court considered that the failure of the donor to take steps to secure the production of the land certificate was decisive.

\section{AUTHORISATION OR ACTUAL DELIVERY?}

Where the land certificate is not in the hands of the donor, the position becomes more difficult. By definition it is not possible for the donor to

${ }^{46}$ See Brunker v Perpetual Trustee Co (Ltd) (1937) 57 CLR 555; Mascall v Mascall (1984) 50 P \& CR 119.

${ }^{47}$ Edwards v Sir Moses Montefiore Jewish Home 1990 NSW LEXIS 10387.

48 Mascall v Mascall (1984) 50 P \& CR 119.

49 (1968) 118 CLR 1, 7.

50 As to the donor's intention, see also Harden v Thompson (1969) 212 EG 1364; Djokovic v Petrovic 1988 NSW LEXIS 9721.

51 [1934] NZLR 1004.

52 (1968) 118 CLR 1. See also Brunker v Perpetual Trustee Co (Ltd) (1937) 57 CLR 555.

${ }^{53}$ See also Brunker v Perpetual Trustee Co (Ltd) (1937) 57 CLR 555, 593.

54 (1990) 169 CLR 540. 


\section{Northern Ireland Legal Quarterly [Vol. 50, No. 1]}

hand the certificate over. Short of retrieving the certificate from the third party, all the donor can do is to authorise the third party to produce the certificate. The question is whether such authorisation is enough to make the gift complete, or whether actual production is required. Typically the problem will arise where the property is subject to a mortgage, as in Corin $\mathrm{v}$ Patton, but the situation can equally arise where the certificate is in the hands of a third party simply for safekeeping. Assuming that the third party would be compellable to produce the certificate for registration of the transfer, will authorisation by the donor suffice for the gift to be regarded as complete?

Different views may be found in the authorities. In Pilewska v Haduch ${ }^{55}$ Wilberforce $\mathbf{J}$ held the gift complete notwithstanding that the land certificate was held by a mortgagee. The judgment does not indicate what steps, if any, had been taken to secure production of the certificate. In $R e$ Ward $^{56}$ Nevile $\mathbf{J}$ held that a gift had been completed where the donor had authorised the release of the land certificate by his solicitors. Authorisation alone was however held in Costin v Costin ${ }^{57}$ to be insufficient to satisfy the test. There a father and son were joint tenants of land. The father executed a voluntary transfer of his share in the property to another son. The land certificate was in the hands of a firm of solicitors, and the father signed an authority to the solicitors to produce the certificate to the Land Titles Office to enable the transfer to be registered. The solicitors informed the father that they required authorisation also from the other joint tenant of the land. In the event this was not forthcoming. The question was whether in these circumstances the gift by the father was effective. At first instance Santow J held it was. On appeal however the New South Wales Court of Appeal held that the test had not been satisfied. Brownie AJA explained that though the donor intended to perfect his gift, he had failed to achieve that aim before changing his intention. According to Sheller JA, although the father had given authorisation for the land certificate to be released, until such time as that authority was acted upon, the authority could be revoked. ${ }^{58}$

If this is correct, the test whether or not a gift is complete depends not on whether the donor has done all that is required of him, but rather on whether he has put the matter beyond his recall. So long as he can countermand his instruction to release the land certificate, the gift is not complete. On one view, this is acceptable enough: the donor's action in making the gift is voluntary, and until the last minute he should be free to change his mind. On another view however, the effectiveness of the gift depends on the vagaries of if and when the party in possession of the land certificate carries out the donor's instruction to hand it over. So far as the the actions of the donor remain relevant, it is his failure to act (ie the absence of any countermanding of his instruction) rather than the positive steps he has taken that is being considered.

55 (1962) 184 EG 11.

56 [1968] WAR 33; (1968) 42 ALJR 226.

571997 NSW LEXIS 261.

${ }^{58}$ Cf Re Anderson [1956] NZLR 661, where in treating the question whether the estate of a deceased testatrix had been finally distributed as the same as whether the trustee of the estate had made an effective gift, McGregor J pointed out that the documents which had been delivered to the beneficiary's solicitors to enable the beneficiary to be registered could not be recalled by the trustee. See also Brunker v Perpetual Trustee Co (Ltd) (1937) 57 CLR 555, 609 (McTiernan J). 
If production of the land certificate rather than authorisation is essential for a gift to be regarded as complete, it is not beyond imagination that a third party who carries out the donor's instructions promptly will bring about the success of a gift while if he had acted less expeditiously the gift could have failed, either by the donor having countermanded his instruction, or dying before the instruction is carried out. ${ }^{59}$ Whether the disappointed donee would have any remedy in the latter case on the basis of White $\mathrm{v}$ Jones $^{60}$ may have to be considered if the courts here adopt the view expressed in Costin v Costin.

\section{JOINT PROPRIETORS}

Another difficulty arises where the land is jointly owned by the donor and another registered proprietor, as in Corin v Patton and Costin v Costin. As was pointed out by Toohey $\mathrm{J}$ in Corin $\mathrm{v}$ Patton,${ }^{61}$ no one of the joint proprietors has an individual land certificate relating to his own interest, "[a]nd so to encompass delivery of the certificate in the steps required of a joint tenant seeking to sever the joint tenancy may be to make a somewhat unreal demand". ${ }^{2}$ In Costin v Costin Sheller JA opined that the land certificate could not have been handed over without the authority of the other joint tenant. The question in these circumstances is whether such other joint tenant could frustrate the intentions of the transferor by refusing to allow the certificate to be lodged for registration of the transfer. If so, severance could clearly not be effected. ${ }^{3}$ This aspect of the difficulty arising from the decision in Costin was considered in Motor Auction Pty Ltd $\mathrm{v}$ John Joyce Wholesale Cars Pty Ltd. ${ }^{64}$ Here again an unregistered transfer failed for want of evidence that the transferor had authorised release of the land certificate to enable registration to take place. In relation to the question of authorisation of the release of the land certificate where there are joint proprietors, Santow J held that it was arguable that all the joint tenants must join in the request to lodge the certificate, but that a joint tenant directed by the putative donor to produce the certificate of title would not be permitted to frustrate registration by refusing to produce or cause production of the certificate. On the basis of Costin v Costin, however, the fact that a third party such as a joint proprietor may be compellable to produce the land certificate may be small consolation for a donee if the donor has, during the time the land certificate is not produced, changed his mind.

\section{ORDERS FOR PRODUCTION}

The Land Registration Act 1925 requires production of the land certificate when a dealing is registered. ${ }^{65}$ Both the Act and the Land Registration Rules enable the Registrar to order production of a certificate. ${ }^{66}$ Similar provisions exist in Northern Ireland. ${ }^{67}$ If a donor hands over a transfer but fails to produce the land certificate, or a third party with the land certificate fails to produce it after being instructed by the donor to do so,

${ }^{59}$ See below.

${ }^{60}$ [1995] 1 All ER 691.

61 (1990) 169 CLR 540.

${ }^{62}$ Ibid, 590.

${ }^{63}$ See concerns of Santow J at first instance in Costin v Costin 1994 NSW LEXIS 13222.

641997 NSW LEXIS 406.

${ }^{65}$ Land Registration Act 1925, s64(1).

${ }^{66} \mathrm{Ibid}$, s64(2); Land Registration Rules 1925, r15.

${ }^{67}$ Land Registration Rules (NI) 1994, rr 128 and 129. 
could the ineffective gift be cured either by the existence of the Registrar's power to order production, or its exercise? In Scoones v Galvin ${ }^{68}$ the New Zealand Court of Appeal thought not in the case of similar New Zealand legislation, saying that if upon being called by the Registrar to produce the certificate a donor refused on the basis that the transaction was by way of gift and that he did not intend to complete the gift, such reply would be an effectual answer to the Registrar's requisition.

\section{DEATH OF DONOR}

In a number of cases the question whether a gift is complete so far as Equity is concerned has arisen because the donor has died before registration has taken place. If the gift is regarded as complete, then the death of the donor has no relevance: the property is already the donee's. So in the Rose cases the court considered that the deceased had made an effective inter vivos gift of shares. The same result was reached in $R e$ Ward $^{69}$ Scoones $\mathrm{v}$ Galvin ${ }^{70}$ and Kennedy $\mathrm{v}$ Tickner $^{71}$ in the case of transfers of land. The fact that the donor dies does not prevent registration taking place thereafter. If however the gift is not seen as complete by the time the donor dies, then the position is otherwise. The donee has no equitable interest which would enable a court to compel the donor's personal representatives to perfect the gift. If in such circumstances the donor was a joint tenant of the property, the absence of any equitable interest in the donee will preclude severance of the jointure, so that the donor's co-proprietor will take by survivorship. ${ }^{72}$ The same result will occur on the basis of the view of Dixon J in Brunker v Perpetual Trustee Co $(L t d),{ }^{73} v i z$ that the donee has no equitable interest in the land transferred, but rather a statutory right to have himself registered as owner. In Corin v Patton ${ }^{74}$ Brennan J held the surviving joint proprietor entitled to the property on the basis that on the death of the donor the statutory right of the donee to be registered became valueless.

In Scoones v Galvin ${ }^{75}$ a question was raised as to the effect of the death of a donor on any instruction given by him to a third party to produce the land certificate. It was argued for the donee that upon the death of the donor a third party in possession of the land certificate could no longer be said to be holding the certificate on behalf of the donor, so that the gift thereupon became complete. Fair $J$ thought that the death of the donor would determine any authority which his solicitor had to produce the title for the purpose of perfecting the gift. This was accepted as correct by Dixon and McTiernan JJ in Brunker $\mathrm{v}$ Perpetual Trustee Co $($ Ltd $){ }^{76}$ On the basis of Costin v Costin ${ }^{77}$ however, any question as to the effect of the donor's death in cancelling his instruction is no longer relevant.

${ }^{68}$ [1934] NZLR 1004, 1019.

69 [1968] WAR 33; (1968) 42 ALJR 226.

70 [1934] NZLR 1004.

71 [1950] NZLR 62.

72 See eg Corin v Patton (1990) 169 CLR 540; Costin v Costin (1997) NSW LEXIS 261.

73 (1937) 57 CLR 555.

74 (1990) 169 CLR 540, 571.

75 [1934] NZLR 1004.

76 (1937) 57 CLR 555, 599 and 609.

77 (1997) NSW LEXIS 261. 


\section{CONCLUSION}

The Commonwealth authorities illustrate some of the problems created by the Re Rose decisions in the case of transfers of registered land. The need for further consideration of the decisions is clear from the judgment of Bryson J in The Minister, Aboriginal Land Rights Act $1983 \mathrm{v}$ Aboriginal Corporation of the National Aboriginal Conference: ${ }^{78}$

"The terms in which the law was stated by Turner LJ in Milroy v Lord ... when applied literally to a system of title by a registration (as in Milroy $\mathrm{v}$ Lord itself) would require that the property be actually transferred to the donee, that is, that the donee should become the registered proprietor. There are statements by judges whose views are entitled to great respect which would accept that less than this is sufficient for the perfect constitution of a gift of the beneficial ownership of land under the Torrens system. The content of any exception has been various stated, while other judges of high reputation restate the matter substantially as in Milroy $\mathrm{v}$ Lord. . . If the view of Griffith CJ [in Anning v Anning] is to prevail there is, in my respectful view, room for much more consideration and exposition of the reasons why the transferor is to be bound in conscience by anything less than the completion of the process of transfer of registered proprietorship. There is a need for exposition of the point at which the transfer of beneficial ownership becomes complete, which must require some recognisable and distinct but as yet undefined act of adherence to the donation or adoption of it by the donee, and must be final so as to be binding on all concerned, including not only the donor and donee, but also public authorities and revenue authorities who are entitled to enforce onerous obligations against the owners of land, and to such an extent that the donor can compel the donee to contribute towards or indemnify the donor against such obligations. There is a need for exposition of the effect of supervening events such as death, liquidation levy of execution, sequestration in bankruptcy and dissolution affecting the donor. . . . There is also a need to expound the maxims that there is no equity to perfect an imperfect gift and that equity does not assist a volunter in their application where the donor or some person acting under him intervenes to impede a course towards registration which the donee could otherwise appear to be able to follow, so as to lodge the transfer and obtain registration without obtaining any judicial remedy: such as where the donor or someone claiming under him lodges a caveat or a transfer to some other person, whether or not for value".

\section{His Honour concluded:}

"there do seem to be advantages in the principle as literally stated in Milroy v Lord, in which only registration makes the gift binding in equity; and not the least advantage is the difficulty of seeing how any other rule relates to the deeply underlying principle in which equitable remedies exist to prevent reliance on legal rights where it would be unconscionable to rely on them".

There is nothing in the authorities since these views were stated to suggest a different conclusion. The objection that adoption of such a principle

\footnotetext{
781992 NSW LEXIS 6753.
} 


\section{Northern Ireland Legal Quarterly [Vol. 50, No. 1]}

would focus attention on the action of a third party (the Registrar) and the speed with which he carries out registration rather than the action of the donor, is of less weight since the decision in Costin v Costin. It is suggested that the disadvantage inherent in adoption of the principle that a gift is not effective until registration takes place is a lesser evil than the difficulties inherent in the Rose cases, illustrated by the recent decisions here and elsewhere concerning registered land. 